\title{
Protection Strategy against Spruce Budworm
}

\author{
David A. MacLean (D) \\ Faculty of Forestry and Environmental Management, University of New Brunswick, POB 4400, \\ Fredericton, NB E3B 5A3, Canada; macleand@unb.ca
}

Received: 9 December 2019; Accepted: 10 December 2019; Published: 12 December 2019

\begin{abstract}
Spruce budworm is one of the most significant forest insects worldwide, in terms of outbreak extent, severity, and economic impacts. As a defoliator, spruce budworm larvae are susceptible to insecticide protection, and improvements in efficacy and reductions in non-target environmental effects have made such protection attractive. In this Special Issue, 12 papers describe the advances in spruce budworm protection, most notably an 'early intervention strategy' approach that after six years of trials in New Brunswick, Canada, shows considerable success to date in reducing budworm outbreak occurrence and severity.
\end{abstract}

Keywords: early intervention strategy; foliage protection; defoliation; monitoring; insecticide application

\section{Introduction}

Spruce budworm (Choristoneura fumiferana (Clem.)) outbreaks are a dominant natural disturbance in forests of Canada and northeastern USA. The last major spruce budworm outbreak in eastern Canada in the 1970s-1980s peaked at 52 million hectares in 1975 [1,2]. Widespread, severe defoliation by this native insect results in large-scale mortality and growth reductions of spruce (Picea sp.) and balsam fir (Abies balsamea (L.) Mill.) forests, and largely determines future age-class structure and productivity. Repeated annual defoliation typically lasts about 10 years during outbreaks, resulting in growth reductions up to $90 \%$ [3], mortality averaging $85 \%$ in mature balsam fir stands [4], and changes in regeneration and succession $[5,6]$. Spruce budworm outbreaks also cause substantial losses in timber and economic production $[7,8]$ and increase the risk of forest fire $[9,10]$. Several papers have discussed spruce budworm population dynamics during outbreaks [11-13], tree mortality [4], and effects on stand development and ecosystem functioning [14,15].

The province of Nova Scotia, Canada decided not to protect forests with insecticide treatments during the severe 1970s-1980s spruce budworm outbreak, and suffered an average of $87 \%$ mortality in mature balsam fir stands [16]. Mortality on Cape Breton Island, Nova Scotia covered 629,900 ha, reduced the growing stock of spruce and fir by $70 \%$ or 21.5 million $^{3}$ [17], and increased the hardwood covertype from $16 \%$ to $36 \%$ [18]. In total, spruce budworm defoliation during eastern Canada's last

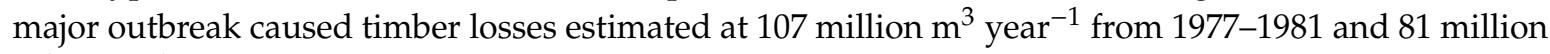
$\mathrm{m}^{3}$ year ${ }^{-1}$ from 1982-1987 [19,20]. To put these amounts in perspective, they were equivalent to $50 \%-70 \%$ of the total 156 million $\mathrm{m}^{3}$ timber harvested in Canada in 2016 [21].

Management to deal with spruce budworm outbreaks has emphasized forest protection by spraying registered insecticides to prevent defoliation and keep trees alive [7]. Other tactics can include salvage harvesting, altering harvest schedules to remove the most susceptible stands, or reducing future susceptibility by planting or thinning [7]. Chemical insecticides are no longer used, and protection strategies use the biological insecticides Bacillus thuringiensis (B.t.) or tebufenozide, an insect-specific growth regulator. To prevent extensive tree mortality caused by spruce budworm defoliation, from 1970 to 1983, the eastern Canadian province of New Brunswick treated an average of two million hectares 
of forest per year with insecticide, at an average cost of $\$ 7.7$ million per year [22]. In comparison, it is estimated that a similar forest insecticide protection program covering two million hectares today would cost between $\$ 90$ and $\$ 160$ million per year, due to increased insecticide active ingredient and application costs [22]. Without insecticide protection, timber harvest reductions are estimated at $18 \%-25 \%$ [7], equivalent to a reduction in timber supply of 2.4-3.3 million $\mathrm{m}^{3}$ year $^{-1}$ in the Atlantic Canada region [23]. The direct and indirect economic losses resulting from an Atlantic Canada region outbreak would be $\$ 10.8-\$ 15.3$ billion CAD, depending on outbreak severity $[8,23]$. Regional job losses over 30 years could total 46,000-56,000 person-years, or approximately 1500-1900 jobs per year [24]. This analysis underestimates job losses during periods of temporary mill closures or in communities where mills could permanently close due to a lack of timber supply.

A large-scale spruce budworm outbreak would also have massive carbon sequestration and greenhouse gas implications [25]. The total potential wood supply loss from a future spruce budworm outbreak in Atlantic Canada projected over 30 years is estimated at 96 million $\mathrm{m}^{3}$, which would generate approximately $66 \mathrm{Mt} \mathrm{CO}_{2}$ emissions [26]. On an annual basis, the emissions from dead and dying trees would be on average $2.21 \mathrm{MT} \mathrm{CO}_{2} \mathrm{e}$, equal to the emissions of an additional 466,000 passenger vehicles [26].

In addition to the compelling economic case for forest protection intervention against spruce budworm outbreaks, there is also considerable public support, as documented in a 2007 public survey [27], which found that $94 \%$ of New Brunswick respondents supported funding research and development on pest control, and $82 \%$ supported controlling future spruce budworm outbreaks.

Over the last five years, a $\$ 30$ million research project has tested another possible management tactic, termed an early intervention strategy, aimed at area-wide management of spruce budworm populations [28]. This includes intensive monitoring to detect 'hotspots' of rising budworm populations before defoliation occurs, targeted insecticide treatment to prevent spread, and detailed research into effects on target and non-target insects [28,29].

\section{Description of Papers in This Special Issue}

The objective of this Protection Strategy against Spruce Budworm Special Issue of Forests was to compile recent research on protection strategies and related topics about detection, monitoring, impacts, population dynamics, and integrated pest management of spruce budworm. The issue includes 12 papers that describe the results and prospects for the use of an early intervention strategy in spruce budworm and other insect management, as well as related topics. A brief description of the content and main findings of the 12 papers in this Protection Strategy against Spruce Budworm Special Issue is as follows.

The first six papers are all directly related to the application and testing of an early intervention strategy:

1 Johns et al. [28] described a conceptual framework for an early intervention strategy against spruce budworm, including all of the core components needed for such a program to be viable. Early intervention and foliage protection strategies against spruce budworm are not necessarily mutually exclusive and core elements are relevant to population control for other insect pests that show hotspot outbreak dynamics [28]. Components required for a spruce budworm protection program to be successful include hotspot monitoring, population control, cost-benefit analyses, and proactive communications with stakeholders [28].

2 MacLean et al. [29] reported positive results after five years of early intervention strategy trials conducted by a consortium of government, forest industry, researchers, and other partners. Following over 420,000 ha of treatments of low but increasing spruce budworm populations, second instar larvae (L2) levels across northern New Brunswick, Canada were considerably lower than populations in adjacent Québec [29]. Blocks treated with Bacillus thuringiensis or tebufenozide insecticide consistently had reduced budworm levels, generally did not require 
treatment in the subsequent year, and areas with moderate or higher L2 populations declined by over $90 \%$ reductions in 2018, while they continued to increase in Québec.

3 Liu et al. [30] investigated the potential economic impacts of future spruce budworm outbreaks on 2.8 million ha of Crown land in New Brunswick and compared early intervention and foliage protection approaches. They found that timber harvest supply from 2017 to 2067 was projected to be reduced by 29 to 43 million $\mathrm{m}^{3}$ by uncontrolled moderate or severe budworm outbreaks, which would reduce total economic output by $\$ 25$ billion (CAD) to $\$ 35$ billion [30]. Depending upon outbreak severity, the early intervention strategy was projected to have benefit/cost ratios of 3.8 to 6.4 and net present values of $\$ 186$ million to $\$ 353$ million, both higher than foliage protection strategies [30].

4 Régnière et al. [31] reported on detailed observations of the dynamics of low but rising spruce budworm populations, the target for early intervention. Results showed strong density-dependent survival between early larval stages and adult emergence, explained by natural enemy impacts and overcrowding, and inverse density-dependence of apparent fecundity, with a net immigration into lower-density populations and net emigration from higher populations at a threshold of about $25 \%$ defoliation [31]. This supported the conclusion that immigration, to elevate budworm above a threshold density of about four L4 larvae branch ${ }^{-1}$ was required for a population to increase to outbreak density [31], which helps set a target treatment density.

5 Régnière and Nealis [32] found strong evidence of density-dependent emigration in both eastern and western spruce budworms, and concluded that migration was not random, but was density-dependent.

6 Zhang et al. [33] tested the influence of a gradient of balsam fir-hardwood species composition on the defoliation of fir during the first five years of a spruce budworm outbreak. Fir defoliation was significantly lower as hardwood content increased, but the relationship varied with overall defoliation severity each year [33]. Results helped to set a fir-hardwood threshold below which insecticide protection is not used.

Four papers were related to specific aspects of spruce budworm management:

$7 \quad \mathrm{Li}$ et al. [34] used spatial autocorrelation analyses to determine patterns of spruce budworm defoliation of trees (clustered, dispersed, or random) and plots. About one-quarter to one-half of plots had significantly clustered defoliation, and data on plot-level defoliation and tree basal area were sufficient for modeling individual tree defoliation [34].

8 Rahimzadeh-Bajgiran et al. [35] assessed the use of Landsat-5 and Landsat-MSS data to detect and map spruce budworm defoliation. A combination of three vegetation indices derived from Landsat data were able to detect and classify defoliation in three classes with an accuracy of $52 \%-77 \%$.

9,10 Régnière et al. [36] described the effects of temperature constraints in an individual-based model of spruce budworm moth migration that was parameterized with observations from moths captured in traps or observed migrating under field conditions. A related paper [37] incorporated crepuscular (evening) circadian rhythms of moth flight activity as influenced by evening temperatures into the model. Given the importance of density-dependent emigration [32] and the requirement for moth immigration to elevate budworm above a threshold for outbreak initiation [31], methods to model and map moth flights are important for budworm monitoring for early intervention.

The final two papers dealt with elements of integrated management of spruce budworm:

11 Régnière et al. [38] reported results of trials of aerial applications of a registered formulation of synthetic spruce budworm female sex pheromone to disrupt mating in populations. Although the pheromone application reduced the capture of male budworm moths in pheromone-baited traps by $90 \%$ and reduced mating success of virgin females held in individual cages at mid-crown, 
results showed that populations of eggs or overwintering larvae in the following generation were not reduced, possibly because of the immigration of mated females [38].

12 Quiring et al. [39] tested the influence of a foliar endophyte and budburst phenology on budworm survival. Survival of budworm larvae to pupation and to adult emergence was $13 \%-17 \%$ lower on endophyte positive trees, suggesting that endopytes inoculated into spruce seedlings could limit the spruce budworm population as part of an early intervention strategy [39].

\section{Conclusions}

Collectively, the 12 papers comprising the Protection Strategy Against Spruce Budworm Special Issue of Forests describe a promising new method to reduce the occurrence or severity of defoliation in outbreaks. Early intervention strategy research continues in New Brunswick, and the most recent (autumn 2019) budworm L2 monitoring data show that populations remain at low levels (www.healthyforestpartnership.ca), while budworm populations in the adjacent province of Québec continued to increase in 2019 [40]. So far, after six years of trials, the early intervention strategy appears to be working.

Funding: This research was funded by the Atlantic Canada Opportunities Agency, Natural Resources Canada, Government of New Brunswick, and forest industry in New Brunswick.

Acknowledgments: The Early Intervention Against Spruce Budworm research project was overseen by the Healthy Forest Partnership, a consortium of researchers, landowners, forestry companies, governments, and forest protection experts. Many scientists and staff of industry and government agencies have made important contributions, without which the project could not have proceeded.

Conflicts of Interest: The author declares no conflict of interest.

\section{References}

1. Kettela, E.G. A Cartographic History of Spruce Budworm Defoliation 1967 to 1981 in Eastern North America; Inf. Rep. DPC-X-14; Canadian Forestry Service; Environment Canada: Ottawa, ON, Canada, 1983; p. 9.

2. Canadian Council of Forest Ministers. National Forestry Database: Forest Insects and Forest Fires Statistics; Canadian Council of Forest Ministers; Natural Resources Canada; Canadian Forest Service: Ottawa, ON, Canada, 2019. Available online: http://nfdp.ccfm.org/ (accessed on 8 December 2019).

3. Ostaff, D.P.; MacLean, D.A. Patterns of balsam fir foliar production and growth in relation to defoliation by spruce budworm. Can. J. For. Res. 1995, 25, 1128-1136. [CrossRef]

4. MacLean, D.A. Vulnerability of fir-spruce stands during uncontrolled spruce budworm outbreaks: A review and discussion. For. Chron. 1980, 56, 213-221. [CrossRef]

5. Virgin, G.V.; MacLean, D.A. Five decades of balsam fir stand development after spruce budworm-related mortality. For. Ecol. Manag. 2017, 400, 129-138. [CrossRef]

6. Baskerville, G.L. Spruce budworm: Super silviculturist. For. Chron. 1975, 51, 138-140. [CrossRef]

7. Hennigar, C.; Erdle, T.; Gullison, J.; MacLean, D. Re-examining wood supply in light of future spruce budworm outbreaks: A case study in New Brunswick. For. Chron. 2013, 89, 42-53. [CrossRef]

8. Chang, W.-Y.; Lantz, V.A.; Hennigar, C.R.; MacLean, D.A. Economic impacts of spruce budworm (Choristoneura fumiferana Clem.) outbreaks and control in New Brunswick, Canada. Can. J. For. Res. 2012, 42, 490-505. [CrossRef]

9. Stocks, B.J. Fire potential in the spruce budworm-damaged forests of Ontario. For. Chron. 1987, 63, 8-14. [CrossRef]

10. James, P.M.A.; Robert, L.-E.; Wotton, B.M.; Martell, D.L.; Fleming, R.A.; Robert, L. Lagged cumulative spruce budworm defoliation affects the risk of fire ignition in Ontario, Canada. Ecol. Appl. 2017, 27, 532-544. [CrossRef]

11. Régnière, J.; Nealis, V.G. Ecological mechanisms of population change during outbreaks of the spruce budworm. Ecol. Entomol. 2007, 32, 461-477. [CrossRef]

12. Johns, R.C.; Flaherty, L.; Carleton, D.; Edwards, S.; Morrison, A.; Owens, E. Population studies of tree-defoliating insects in Canada: A century in review. Can. Entomol. 2016, 148, S58-S81. [CrossRef] 
13. Royama, T.; Eveleigh, E.S.; Morin, J.R.B.; Pollock, S.J.; McCarthy, P.C.; McDougall, G.A.; Lucarotti, C.J. Mechanisms underlying spruce budworm outbreak processes as elucidated by a 14-year study in New Brunswick, Canada. Ecol. Monogr. 2017, 87, 600-631. [CrossRef]

14. Kneeshaw, D.; Sturtevant, B.R.; Cooke, B.; Work, T.; Pureswaran, D.; DeGrandpre, L.; MacLean, D.A. Insect disturbances in forest ecosystems. Chapter 7. In Routledge Handbook of Forest Ecology; Peh, K.S.-H., Corlett, R.T., Bergeron, Y., Eds.; Routledge: Oxon, UK, 2015; pp. 93-113.

15. MacLean, D.A. Impacts of insect outbreaks on tree mortality, productivity, and stand development. Can. Entomol. 2016, 148, S138-S159. [CrossRef]

16. MacLean, D.A.; Ostaff, D.P. Patterns of balsam fir mortality caused by an uncontrolled spruce budworm outbreak. Can. J. For. Res. 1989, 19, 1087-1095. [CrossRef]

17. Nova Scotia Department of Lands and Forests. The Current Status of the Softwood Resource on Cape Breton Island; Nova Scotia Department of Lands and Forests: Truro, NS, Canada, 1982; p. 2.

18. Nova Scotia Department of Natural Resources. Impact of the 1974-81 Spruce Budworm Infestation on the Forests of Cape Breton Island; Nova Scotia Department of Natural Resources: Halifax, NS, Canada, 1994; p. 8.

19. Sterner, T.E.; Davidson, A.G. Forest Insect and Disease Conditions in Canada, 1981; Canadian Forest Service: Ottawa, ON, Canada, 1982.

20. Power, J.M. National data on forest pest damage. In Canada's Timber Resources; Inf. Rep., PI-X-101; Brand, D.G., Ed.; Canadian Forest Service: Ottawa, ON, Canada, 1991; pp. 119-129.

21. Natural Resources Canada. Statistical Data on Canada's Forest Resources. 2019. Available online: https://www.nrcan.gc.ca/forests/resources/13507 (accessed on 8 December 2019).

22. Forest Protection Limited. Spruce Budworm Aerial Treatment Program Areas and Costs, 1970-1993; Forest Protection Limited: Fredericton, NB, Canada, 1993.

23. MacLean, D.A. Potential Economic Losses from the Next Spruce Budworm Outbreak; Report prepared for Forest Protection Limited; Forest Protection Limited: Fredericton, NB, Canada, 2013; p. 15, unpublished work.

24. MacLean, D.A. Potential Regional Employment Losses from an Uncontrolled Spruce Budworm Outbreak; Report prepared for New Brunswick Spruce Budworm Technical Committee; New Brunswick Spruce Budworm Technical Committee: Fredericton, NB, Canada, 2013; p. 1, unpublished work.

25. Dymond, C.; Neilson, E.; Stinson, G.; Porter, K.; MacLean, D.A.; Gray, D.; Campagna, M.; Kurz, W. Future spruce budworm outbreak may create a carbon source in eastern Canadian forests. Ecosystems 2010, 13, 917-931. [CrossRef]

26. MacLean, D.A. Effects of the Next Spruce Budworm Outbreak on Greenhouse Gases and Climate Change; Report prepared for the Healthy Forest Partnership; The Healthy Forest Partnership: Fredericton, NB, Canada, 2017; p. 6, unpublished work.

27. Chang, W.-Y.; Lantz, V.A.; MacLean, D.A. Public attitudes about forest pest outbreaks and control options: Case studies in two Canadian provinces. For. Ecol. Manag. 2009, 257, 1333-1343. [CrossRef]

28. Johns, R.C.; Bowden, J.J.; Carleton, D.R.; Cooke, B.J.; Edwards, S.; Emilson, E.J.S.; James, P.M.A.; Kneeshaw, D.; MacLean, D.A.; Martel, V.; et al. A conceptual framework for the spruce budworm early intervention strategy: Can outbreaks be stopped? Forests 2019, 10, 910. [CrossRef]

29. MacLean, D.A.; Amirault, P.; Amos-Binks, L.; Carleton, D.; Hennigar, C.; Johns, R.; Régnière, J. Positive results of an early intervention strategy to suppress a spruce budworm outbreak after five years of trials. Forests 2019, 10, 448. [CrossRef]

30. Liu, E.Y.; Lantz, V.A.; MacLean, D.A.; Hennigar, C. Economics of early intervention to suppress a potential spruce budworm outbreak on Crown land in New Brunswick, Canada. Forests 2019, 10, 481. [CrossRef]

31. Régnière, J.; Cooke, B.J.; Béchard, A.; Dupont, A.; Therrien, P. Dynamics and management of rising outbreak spruce budworm populations. Forests 2019, 10, 748. [CrossRef]

32. Régnière, J.; Nealis, V.G. Density dependence of egg recruitment and moth dispersal in spruce budworms. Forests 2019, 10, 706. [CrossRef]

33. Zhang, B.; MacLean, D.A.; Johns, R.C.; Eveleigh, E.S. Effects of hardwood content on balsam fir defoliation during the building phase of a spruce budworm outbreak. Forests 2018, 9, 530. [CrossRef]

34. Li, M.; MacLean, D.A.; Hennigar, C.R.; Ogilvie, J. Spatial-temporal patterns of spruce budworm defoliation within plots in Québec. Forests 2019, 10, 232. [CrossRef]

35. Rahimzadeh-Bajgiran, P.; Weiskittel, A.R.; Kneeshaw, D.; MacLean, D.A. Detection of annual spruce budworm defoliation and severity classification using Landsat imagery. Forests 2018, 9, 357. [CrossRef] 
36. Régnière, J.; Delisle, J.; Sturtevant, B.R.; Garcia, M.; Saint-Amant, R. Modeling migratory flight in the spruce budworm: Temperature constraints. Forests 2019, 10, 802. [CrossRef]

37. Régnière, J.; Garcia, M.; Saint-Amant, R. Modeling migratory flight in the spruce budworm: Circadian rhythm. Forests 2019, 10, 877. [CrossRef]

38. Régnière, J.; Delisle, J.; Dupont, A.; Trudel, R. The impact of moth migration on apparent fecundity overwhelms mating disruption as a method to manage spruce budworm populations. Forests 2019, 10, 775. [CrossRef]

39. Quiring, D.; Adams, G.; Flaherty, L.; McCartney, A.; Miller, J.D.; Edwards, S. Influence of a foliar endophyte and budburst phenology on survival of wild and laboratory-reared eastern spruce budworm, Choristoneura fumiferana on white spruce (Picea glauca). Forests 2019, 10, 503. [CrossRef]

40. Québec Ministère des Forêts, de la Faune et des Parcs. Aires Infestées par la Tordeuse des Bourgeons de L'épinette au Québec en 2019; Gouvernement du Québec, Direction de la Protection des Forêts: Quebec City, QC, Canada, 2019; p. 32.

(C) 2019 by the author. Licensee MDPI, Basel, Switzerland. This article is an open access article distributed under the terms and conditions of the Creative Commons Attribution (CC BY) license (http://creativecommons.org/licenses/by/4.0/). 